\title{
POTENSI LIMBAH PADAT PERKEBUNAN KELAPA SAWIT DI PROVISI RIAU
}

\author{
(Potential Of Solid Waste Oil Palm Plantion In Riau Province) \\ Rina Novia Yanti ${ }^{1}$, Ika Lestari ${ }^{1}$ \\ ${ }^{1}$ Dosen Fakultas Kehutanan, Universitas Lancang Kuning \\ Jln. Yos Sudarso Km. 8 Rumbai Pekanbaru Riau Telp./Fax. (0761) 54092 \\ Email: rina.fahutan@gmail.com, lestariika32@gmail.com
}

Diterima: 07 Agustus 2020, Direvisi: 14 September 2020, Disetujui: 23 Oktober 2020

DOI: $10.31849 /$ forestra.v15i2.4696

\begin{abstract}
Oil palm plantations produce solid biomass waste, namely replanting stems, midribs, empty fruit bunches (EFB), shells and fruit fibers. In 2018 the area of oil palm plantations in Indonesia reached 14.3 million ha and the area of oil palm plantations in the Riau Province until 2018 was 2.7 million hectares. The availability of oil palm plantation waste in Riau Province, such as waste production in gardens and palm oil mill waste (PKS) needs to be studied further, so that the amount of oil palm biomass waste will be illustrated. The purpose of this study was to calculate the potential for biomass waste from oil palm plantations in the form of replanting stems, midribs, EFB, shells and fruit fibers. The method used in this study is calculating waste based on mass balance and the data were analyzed using linear regression. The results of this study indicate an increasing trend in the amount of waste produced. The most potential amount of waste is oil palm empty bunches (TKKS) of 6663956 tonnes per year on average.
\end{abstract}

Keywords: biomassa waste, fiber, EFB, shells, stem

\begin{abstract}
ABSTRAK
Perkebunan kelapa sawit menghasilkan limbah biomassa padat yaitu batang hasil replanting, pelepah, tandan kosong kelapa sawit (TKKS), cangkang dan serat buah. Tahun 2018 luas perkebunan kelapa sawit di Indonesia mencapai 14.3 juta ha dan luas perkebunan kalapa sawit di Provnsi Riau sampai tahun 2018 adalah 2.7 juta hektar. Ketersediaan limbah perkebunan kelapa sawit di Provinsi Riau seperti produksi limbah di kebun dan limbah pabrik kelapa sawit (PKS) perlu dikaji lebih lanjut, sehingga akan tergambar jumlah limbah biomassa kelapa sawit. Tujuan penelitian ini adalah menghitung potensi limbah biomassa perkebunan kelapa sawit dalam bentuk batang hasil replanting, pelepah, TKKS, cangkang dan serat buah. Metode yang digunakan dalam penelitian ini adalah metode perhitungan limbah berdasarkan neraca massa
\end{abstract}


dan data dianalisis menggunakan regresi linier. Hasil penelitian ini menunjukan adanya trend kenaikan jumlah limbah yang dihasilkan. Jumlah limbah yang paling potensial adalah limbah tandan kosong kelapa sawit (TKKS) sebesar 6663956 ton rata-rata pertahun

Kata kunci: batang, cangkang, TKKS, limbah biomassa, serat buah.

\section{PENDAHULUAN}

Indonesia merupakan negara dengan perkebunan kelapa sawit terluas di dunia. Tahun 2018 luas perkebunan kelapa sawit di Indonesia mencapai 14.3 juta ha dan luas perkebunan kalapa sawit di Provnsi Riau sampai tahun 2018 adalah 2.7 juta hektar (BPS 2019). Peningkatan luas perkebunan kelapa sawit (PKS) berimplikasi pada peningkatan jumlah limbah biomassa kebun seperti batang hasil replanting, pelepah, tandan kosong kelapa sawit (TKKS), cangkang dan serat buah. Menurut Fang (2011) jenis limbah padat, cair, dan gas dihasilkan setelah proses produksi minyak kelapa sawit. Sedangkan limbah padat limbah batang, pelepah yang da di kebun dan limbah yang ada dipabrik berupa TKKS, cangkang kelapa kawit, serabut kelapa sawit dan bentuk cair yang dikenal dengan POME (Palm Oil Mills Effluent). Sementara itu, limbah gas bersumber dari gas buangan pabrik kelapa sawit pada proses produksi CPO dari perkebunan kelapa sawi.

Biomassa perkebunan kelapa sawit dimanfaatkan untuk berbagai keperluan seperti TKKS untuk pupuk kompos, biochar batang dan pelepah dimanfaatkan untuk kompos, pakan ternak, cangkang dan serat sebagai bahan bakar boiler di industri pabrik kelapa sawit (PKS0 (Haryati et.al 014). Bahkan Munthe et al. (2015) telah memanfaatkan cangkangnya untuk meningkatkan kualitas nilai kalor, kadar air, densitas, dan kadar abu untuk bahan baku pembuatan biobriket arang. Konversi biomassa perkebunan kelapa sawit menjadi produk yang mempunyai nilai tambah, juga memiliki potensi sebagai sumber energi terbarukan. Pemanfaatan sebagai sumber energi ramah lingkungan akan memberikan dampak positif terhadap lingkungan seperti pengurangan emisi $\mathrm{CO} 2$. Alternatif pemanfaatan lain adalah bahan baku bio oil 
untuk substitusi energi ramah lingkungan pengganti bahan bakar fosil menggunakan proses pirolisis. Pirolisis adalah dekomposisi selulosa, hemiselulosa dan lignin oleh panas dengan suhu tinggi $300-500{ }^{\circ} \mathrm{C}$ tanpa oksigen atau dalam keadaan kekurangan oksigen (Bridgwater 2012).

Ketersediaan limbah perkebunan kelapa sawit di Indonesia seperti produksi limbah di kebun dan limbah pabrik kelapa sawit (PKS) perlu dikaji lebih lanjut, sehingga akan tergambar pola data luas lahan, limbah biomassa dan produksi CPO kelapa sawit. Untuk itu perlu dilakukan perhitungan jumlah biomassa dalam bentuk batang hasil replanting pelepah, TKKS, cangkang dan serat buah, untuk mendapatkan gambaran potensi limbah biomassa untuk bahan baku energi terbarukan.

Produksi 1 ton tandan buah segar (TBS) di areal perkebunan di Malaysia akan menghasilkan limbah padat berupa TKKS $23 \%$, cangkang $5.5 \%$, serat $13.5 \%$, sedangkan limbah yang berasal dari kebun berupa batang hasil replanting $70 \%$ dari 40.1 ton/ha dan pelepah $27.03 \%$ dari 10.4 ton/ha (Abnisa et al. 2013). Menurut Hambali Rina Novia Yanti, Ika Lestari/Wahana Forestra: Jurnal Kehutanan Vol 15 No 02/2020
(2010) komposisi TBS didominasi oleh TKKS (21\%), buah $(65.5 \%)$ dan kondesat (13.5\%), sedangkan sisanya, merupakan cangkang (6.4\%), fiber (14.4\%). Dalam proses produksi CPO, 1 ton TBS menghasilkan $200 \mathrm{~kg}$ crude palm oil (CPO) dan limbah padat TKKS $250 \mathrm{~kg}$. Tujuan penelitian adalah menghitung potensi limbah biomassa perkebunan kelapa sawit di Provinsi Riau dan menentukan limbah mana yang paling berpotensi untuk bahan baku energi terbarukan.

\section{METODE PENELITIAN}

Data yang digunakan dalam penelitian ini adalah data sekunder perkebunan kelapa sawit di Provinsi Riau yang diperoleh dari beberapa sumber yaitu Badan Pusat Statistika (BPS), Dinas Tanaman Pangan Holtikultura dan Perkebunan Provinsi Riau dan Statistik Perkebunan Indonesia Direktorat Jenderal Perkebunan. Data yang digunakan adalah data luas lahan perkebunan kelapa sawit dari tahun 2004 sampai 2018 yang dibagi menjadi 3 (tiga) kelompok yaitu TBM (tanaman belum menghasilkan), TM (tanaman menghasilkan) dan TTR (tanaman tua rusak). 
Data produksi CPO juga digunakan dalam penelitian ini. Hasil perhitungan limbah biomassa terbagi menjadi 5 yaitu, limbah batang, pelepah, tandan kosong kelapa sawit (TKKS), cangkang dan serat buah. Perhitungan biomassa limbah perkebunan kelapa sawit dihitung berdasarkan neraca massa pengolahan tandan buah segar (Hambali 2010). Produksi TKKS yaitu 21\%, cangkang $6,4 \%$, fiber $14,4 \%$, batang $=73$ ton/hasil $\mathrm{x}$ (TT/TR) dan pelepah $=18$ pelepah/pohon x 130 pohon/ha x luas $\mathrm{TM}+2$ ton/ha $\mathrm{x}$ luas TT/TTR.

\section{Analisis Data}

Data sekunder biomassa perkebunan kelapa sawit dianalisis menggunakan:

1. Analisis statistika regresi sederhana/linier.

2. Statistika deskriptif yang meliputi ringkasan data dari beberapa sumber, grafik, dan plot time series dari luas lahan, produksi CPO dan hasil perhitungan limbah biomassa.

3. Melakukan prediksi atau peramalan dengan menggunakan analisis deret waktu (time series analysis). Analisis deret waktu yang digunakan disesuaikan dengan plot time series yang terbentuk dari data.

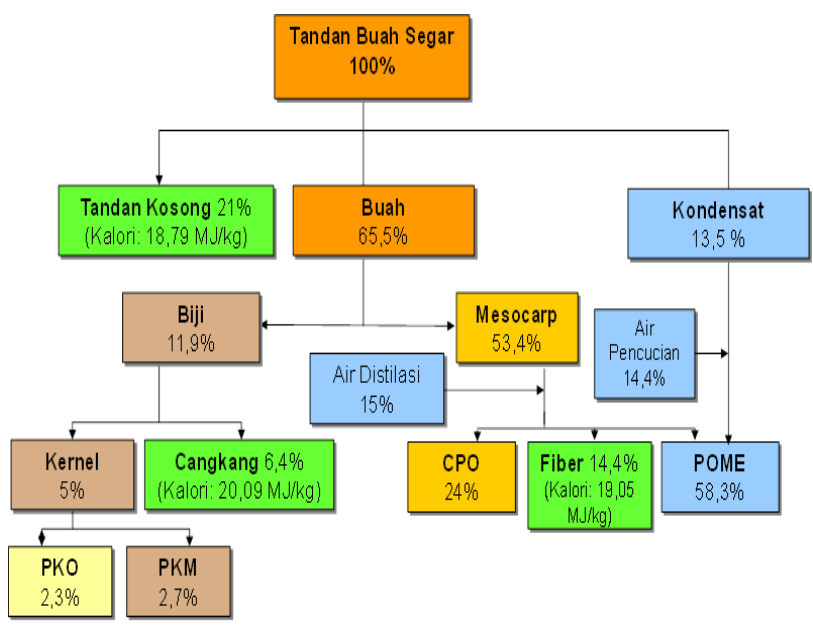

Gambar 1. Neraca massa pengolahan tandan buah segar kelapa sawit (Hambali 2010).

\section{HASIL DAN PEMBAHASAN Peramalan Dengan Menggunakan Analisis Deret Waktu}

Tabel 1 merupakan data ramalan 15 tahun ke depan untuk data luas lahan berdasarkan data BPS tahun 2004-2018. Tabel 1 menunjukkan bahwa luas lahan perkebunan kelapa sawit dalam 15 tahun ke depan cenderung akan terus bertambah. Meskipun, pada tahun-tahun tertentu luas lahan tanaman belum menghasilkan (TBM) 
dan tanaman tua rusak (TTR) ada yang mengalami penurunan. Namun, jika dilihat dari perbedaan total dan rata-rata antara 13 tahun yang tersedia dengan 15 tahun yang akan datang, lahan perkebunan kelapa sawit cenderung mengalami peningkatan. Terutama dapat dillihat pada lahan TTR yang mengalami peningkatan yang cukup signifikan. Hal ini kemungkinan besar disebabkan oleh TTR merupan kelapa sawit yang telah ditanam 25 tahun sebelum tahun dihitung sebagai TTR. Sehingga, peningkatan perkebunan kelapa sawit setiap tahunnya akan membuat lahan TTR 15 tahun yang akan datang akan mengalami peningkatan yang signifikan.

Berdasarkan RTRWP (Rencana Tata Ruang Wilayah Provinsi) Provinsi Riau melalui Perda No. 10 tahun 2018, bahwa luas lahan perkebunan kelapa sawit hanya maksimal 3,1 juta ha. Sehingga dengan melihat hasil prediksi luas lahan pada tabel 3, ini berarti bahwa luas lahan sawit pada tahun 2024 sudah mencapai 3025.758 ha. Hal ini menunjukan bahwa luas maksimal sesuai RTRWP tersebut akan tercapai sekitar tahun 2029. Juga adanya Instruksi Presiden ( Inpres) No 8 tahun 2018 tentang Penundaan evaluasi Perijinan Perkebunan Kelapa Sawit. Penetapan ini tentu akan berakibat pada luasan perkebunan kelapa sawit tidak mengalami penambahan serta banyak limbah yang dihasilkan setiap tahunnya. Sedangkan berdasarkan analisis regresi antara luas lahan dan jumlah limbah yang dihasilkan memiliki hubungan yang signifikan. Sehingga jika pada tahun 2029 luas lahan sawit tidak lagi bertambah, maka artinya limbah yang dihasilkan pun tidak bertambah.

Tabel 1. Prediksi luas lahan kelapa sawit 15 tahun ke depan (2019-2033) di Provinsi Riau

\begin{tabular}{llllrl}
\hline \multirow{2}{*}{ No } & \multirow{2}{*}{ Tahun } & \multicolumn{5}{c}{ Luas Lahan (Ha) } \\
\cline { 3 - 6 } & & TBM & TM & TTR & \multicolumn{1}{c}{ TOTAL } \\
\hline 1 & 2019 & 298645 & 2244549 & 61832 & 2605026 \\
2 & 2020 & 387729 & 2332605 & 34269 & 2754603 \\
3 & 2021 & 315611 & 2420662 & 65395 & 2801668 \\
4 & 2022 & 397316 & 2508719 & 77765 & 2983800
\end{tabular}




\begin{tabular}{|c|c|c|c|c|c|}
\hline 5 & 2023 & 321267 & 2596776 & 77184 & 2995227 \\
\hline 6 & 2024 & 298645 & 2684833 & 42280 & 3025758 \\
\hline No & Tahun & $\begin{array}{c}\text { Luas Lahan } \\
\text { (Ha) }\end{array}$ & No & & Tahun \\
\hline 7 & 2025 & 387729 & 2772890 & 79839 & 3240458 \\
\hline 8 & 2026 & 315611 & 2860947 & 94042 & 3270600 \\
\hline 9 & 2027 & 397316 & 2949004 & 92537 & 3438857 \\
\hline 10 & 2028 & 321267 & 3037060 & 50291 & 3408618 \\
\hline 11 & 2029 & 298645 & 3125117 & 94283 & 3518045 \\
\hline 12 & 2030 & 387729 & 3213174 & 110319 & 3711222 \\
\hline 13 & 2031 & 315611 & 3301231 & 107889 & 3724731 \\
\hline 14 & 2032 & 397316 & 3389288 & 58303 & 3844907 \\
\hline 15 & 2033 & 321267 & 3477345 & 108727 & 3907339 \\
\hline \multicolumn{2}{|c|}{ Total } & 5880287 & 47139127 & 1267393 & 54286807 \\
\hline \multicolumn{2}{|c|}{ Total 13 tahun sebelum } & 4408827 & 19317600 & 298327 & 24025297 \\
\hline \multicolumn{2}{|c|}{ Rata - rata } & 345899 & 2772890 & 74553 & 3193342 \\
\hline \multicolumn{2}{|c|}{ Rata-rata 13 tahun sebelum } & 339141 & 1485969 & 22990 & 1848100 \\
\hline
\end{tabular}

Sumber: Hasil survey KHDTK ,2018

Ramalan luas lahan perkebunan kelapa sawit di Provinsi Riau dari tahun 2019 - 2033 tanaman menghasilkan (TM) dan tanaman tidak produktif (TTR) cenderung mempunyai luas tetap. Hal ini disebabkan tanaman sudah ada sejak awal ramalan. Rata - rata umur kelapa sawit berkisar 30 tahun baru dilakukan replanting. Sedangkan untuk tanaman belum menghasilkan (TBM) ada kecenderungan grafik terus naik, artinya tarjadi pertambahan luas setiap tahunnya, baik perkebunan milik rakyat, permerintah maupun perkebunan milik swasta.
Tabel 2 merupakan hasil prediksi atau peramalan dari limbah biomassa kelapa sawit 15 tahun ke depan, diperkirakan limbah biomassa akan semakin meningkat seiring dengan bertambahnya luas lahan. Perkembangan luas perkebunan kelapa sawit di Provinsi Riau akan terhambat dengan telah disahkannya RTRW Provinsi Riau, dimana peruntukan perkebunan kelapa sawit ditetapka seluas 3,1 juta hektar yang diprediksi akan terpenuhi pada tahun 2029. 
Tabel 2 Prediksi limbah biomassa kelapa sawit 15 tahun ke depan (2019-2033)

\begin{tabular}{|c|c|c|c|c|c|c|}
\hline \multirow[t]{2}{*}{ No } & \multirow[t]{2}{*}{ Tahun } & \multicolumn{5}{|c|}{ Limbah Biomassa (Ton) } \\
\hline & & Batang & Pelepah & Tandan kosong & Serabut & Cangkang \\
\hline 1 & 2019 & 4513727 & 3623201 & 8089978 & 1904124 & 2465517 \\
\hline 2 & 2020 & 2501607 & 3781344 & 8451761 & 1988665 & 2575775 \\
\hline 3 & 2021 & 4773839 & 3939488 & 8813543 & 2073205 & 2686032 \\
\hline 4 & 2022 & 5676809 & 4097632 & 9175326 & 2157745 & 2796290 \\
\hline 5 & 2023 & 5634455 & 4255776 & 9537108 & 2242285 & 2906547 \\
\hline 6 & 2024 & 3086437 & 4413920 & 9689891 & 2326825 & 3016805 \\
\hline 7 & 2025 & 5828250 & 4572064 & 10260674 & 2411365 & 3127062 \\
\hline 8 & 2026 & 6865049 & 4730208 & 10622456 & 2495905 & 3237320 \\
\hline 9 & 2027 & 6755183 & 4888352 & 10984239 & 2580445 & 3347577 \\
\hline 10 & 2028 & 3671267 & 5046496 & 11346021 & 2664985 & 3457835 \\
\hline 11 & 2029 & 6882661 & 5204640 & 11707804 & 2749525 & 3568093 \\
\hline 12 & 2030 & 8053289 & 5362784 & 12069586 & 2834065 & 3678350 \\
\hline 13 & 2031 & 7875911 & 5520928 & 12431369 & 2918605 & 3788608 \\
\hline 14 & 2032 & 4256096 & 5679072 & 12793151 & 3003145 & 3898865 \\
\hline 15 & 2033 & 7937072 & 5837216 & 13154934 & 3087685 & 4009123 \\
\hline \multirow{2}{*}{\multicolumn{2}{|c|}{ Total }} & 92519 & 77725 & 174431450 & 40993202 & 53160061 \\
\hline & & 650 & 091 & & & \\
\hline \multirow{2}{*}{\multicolumn{2}{|c|}{$\begin{array}{l}\text { Total } 13 \\
\text { tahun sebelum }\end{array}$}} & 21817 & 28598 & 63431514 & 15272196 & 19331509 \\
\hline & & 499 & 763 & & & \\
\hline \multicolumn{2}{|c|}{ Rata-rata } & 5442332 & 4572064 & 10260674 & 2411365 & 3127062 \\
\hline \multicolumn{2}{|c|}{$\begin{array}{l}\text { Rata-rata } 13 \\
\text { tahun sebelum }\end{array}$} & 1678269 & 2199905 & 4879347 & 1174784 & 1487039 \\
\hline
\end{tabular}

Ketersediaan limbah biomassa karena total limbah TKKS sebesar 11346 perkebunan kelapa sawit setiap tahunnya 021 ton pada tahun 2028. Dilihat dari terus mengalami peningkatan, terutama limbah TKKS. Limbah TKKS mempunyai tren kenaikan yang sangat tajam alternatif.

dibandingkan dengan limbah batang, pelepah, Sedangkan hasil prediksi dari hasil cangkang dan serabut. Hal ini disebabkan ketersediaan, limbah TKKS paling perpotensi menjadi bahan baku biomass untuk energi

produksi CPO 15 tahun disampaikan pada 
Tabel 3, dimana produksi CPO dalam 15 tahun kedepan, akan meningkat seiring bertambahnya lahan. Peramalan ini dibatasi berdasarkan pola data pada tahun-tahun yang tersedia (15 tahun), tidak melihat faktor lain, seperti struktur tanah, jenis pupuk, jenis mesin, bencana alam dan lain sebagainya. Untuk melihat pengaruh luas lahan TTR pada limbah batang dan luas lahan TM terhadap hasil CPO akan dilakukan dengan analisis regresi sederhana menggunakan data aktual dan data hasil peramalan.

Tabel 3 Prediksi hasil produksi CPO 15 tahun ke depan (2019-2033) di Provinsi Riau

\begin{tabular}{|c|c|c|c|c|c|}
\hline No & Tahun & Produksi CPO & No & & $\begin{array}{l}\text { Produksi } \\
\text { CPO (ton) }\end{array}$ \\
\hline 1 & 2019 & 9245690 & 11 & 2029 & 13380347 \\
\hline 2 & 2020 & 9659155 & 12 & 2030 & 13793813 \\
\hline 3 & 2021 & 10072621 & 13 & 2031 & 14207278 \\
\hline 4 & 2022 & 10486087 & 14 & 2032 & 14620744 \\
\hline 5 & 2023 & 10899553 & 15 & 2033 & 15034210 \\
\hline 6 & 2024 & 11313018 & \multicolumn{2}{|l|}{ Total } & 185358956 \\
\hline 7 & 2025 & 11726484 & \multicolumn{2}{|c|}{ Total 13 tahun sebelum } & 72493159 \\
\hline 8 & 2026 & 12139950 & \multicolumn{2}{|c|}{ Rata-rata } & 13239925 \\
\hline 9 & 2027 & 12553415 & \multicolumn{2}{|c|}{ Rata-rata 13 tahun } & 5576397 \\
\hline 10 & 2028 & 12966881 & & & \\
\hline
\end{tabular}

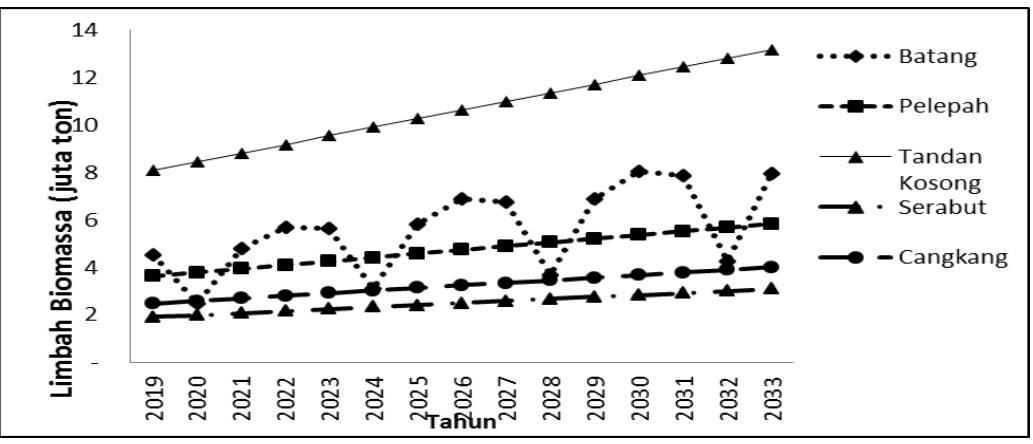

Gambar 2. Grafik trend ketersediaan bahan biomassa perkebunan kelapa sawit sampai tahun 2033 
Gambar 2 memperlihatkan bahwa gambaran potensi limbah batang sawit terjadi naik turun, hal ini disebabkan karena tahapan replanting yang tidak seragam. Tanaman sawit yang sudah mencapai masa tidak produktif lagi yaitu umur 25 - 30 tahun dilakukan penebangan, sedangkan di petak yang lain jika masih produktif maka tidak dilakukan penebangan.

\section{Analisis Regresi}

Regresi sederhana/linier dilakukan pada peubah respon limbah batang terhadap peubah prediktor luas lahan TTR, limbah tandan kosong terhadap peubah prediktor produksi $\mathrm{CPO}$, limbah cangkang terhadap produksi $\mathrm{CPO}$, serta produksi $\mathrm{CPO}$ terhadap luas lahan TM. Sedangkan regresi berganda diterapkan pada peubah respon limbah pelepah terhadap peubah prediktor luas lahan
TM dan luas lahan TTR, respon limbah serabut terhadap peubah prediktor luas lahan TM dan luas lahan TTR.

Data aktual hasil uji statistika berdasarkan nilai-p menunjukkan hasil pengaruh nyata hubungan peubah prediktor. Kecuali pada hubungan limbah serabut dan luas lahan TTR, dengan nilai-p 0.729. Hal ini menunjukkan bahwa tidak ada hubungan antara jumlah limbah serabut dengan luas lahan TTR. Pada data ramalan, hasil uji statistik menunjukkan bahwa tidak ada hubungan antara jumlah limbah pelepah dengan luas lahan TTR. Hal yang sama pada limbah serabut dengan luas lahan TTR, seperti pada data aktual data hasil prediksi menunjukkan tidak adanya relasi antara jumlah limbah serabut dengan luas lahan TTR. Secara lebih lengkap hasil uji statistik dapat dilihat pada Tabel 4.

Tabel 4. Hasil uji statistika untuk data aktual dan data ramalan

\begin{tabular}{|c|c|c|c|c|c|c|}
\hline No & Peubah respon & Peubah prediktor & Jenis analisis & $\begin{array}{l}\text { Pengaruh } \\
\text { prediktor } \\
\text { terhadap } \\
\text { respon }\end{array}$ & Nilai $\mathrm{p}$ & Kesimpulan \\
\hline \multicolumn{7}{|c|}{ Data Aktual } \\
\hline 1 & Limbah batang & Luas lahan TTR & $\begin{array}{l}\text { Regresi } \\
\text { sederhana }\end{array}$ & 73 & 0 & $\begin{array}{l}\text { Berpengaruh } \\
\text { nyata }\end{array}$ \\
\hline 2 & Limbah pelepah & 1. Luas lahan TM & Regresi & 1.4 & 0 & Berpengaruh \\
\hline
\end{tabular}




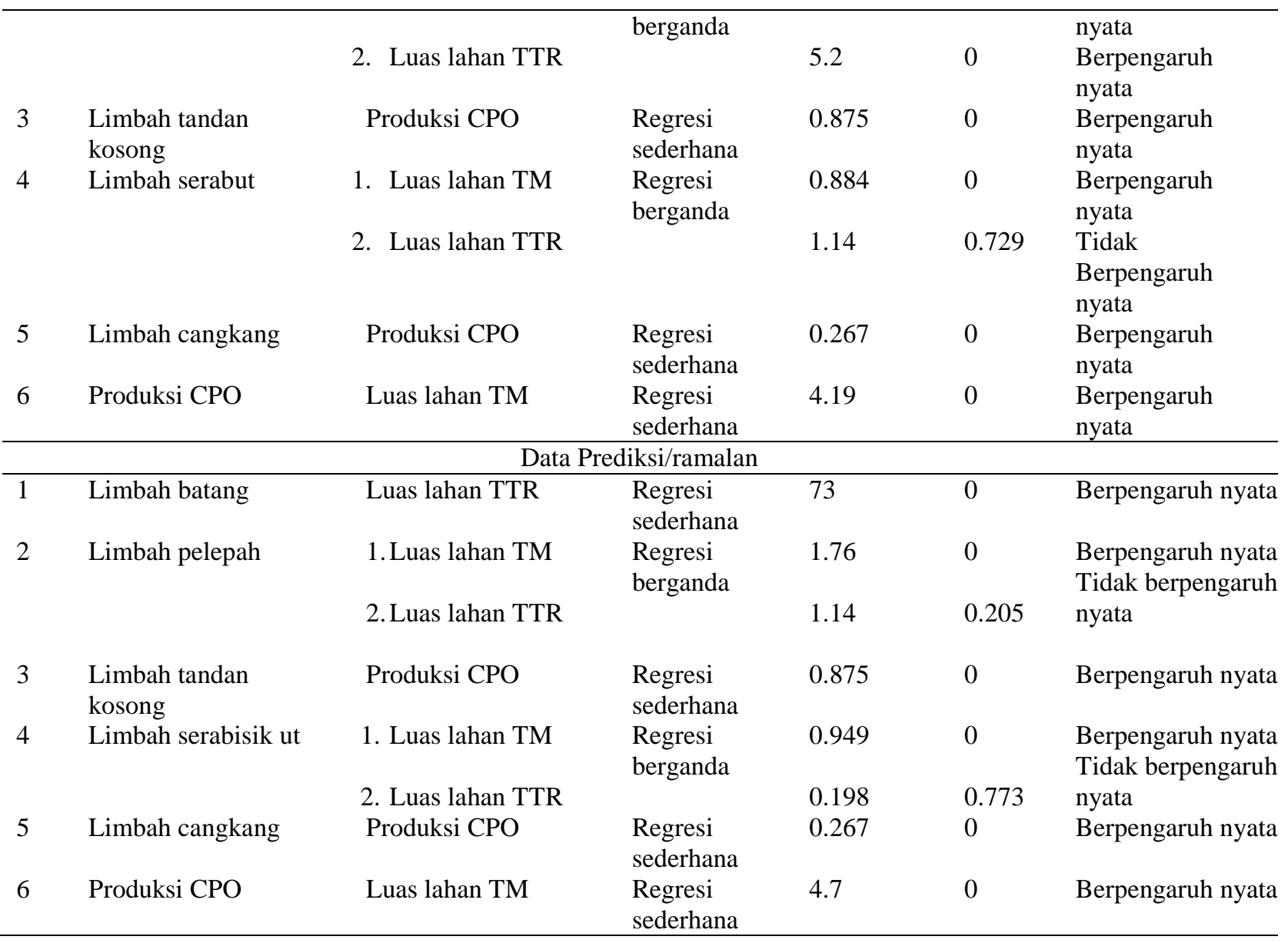

\section{KESIMPULAN DAN SARAN}

A. Kesimpulan

1. Data ramalan 15 tahun ke depan untuk data luas lahan berdasarkan data BPS tahun 2004-2018 menunjukkan bahwa luas lahan perkebunan kelapa sawit dalam 15 tahun ke depan cenderung akan terus bertambah. Meskipun, pada tahuntahun tertentu luas lahan tanaman belum menghasilkan (TBM) dan tanaman tua rusak (TTR) ada yang mengalami penurunan.

2. Hasil prediksi atau peramalan dari limbah biomassa kelapa sawit 15 tahun ke depan, diperkirakan limbah biomassa akan semakin meningkat seiring dengan bertambahnya luas lahan. 
3. Hasil uji statistika berdasarkan nilai$\mathrm{p}$ menunjukkan hasil pengaruh nyata hubungan peubah prediktor. Kecuali pada hubungan limbah serabut dan luas lahan TTR, dengan nilai-p 0.729. Hal ini menunjukkan bahwa tidak ada hubungan antara jumlah limbah serabut dengan luas lahan TTR. Pada data ramalan, hasil uji statistik menunjukkan bahwa tidak ada hubungan antara jumlah limbah pelepah dengan luas lahan TTR.

\section{B. Saran}

Perlu dilakukan kajian lebih lanjut terkait potensi limbah perkebunan kelapa sawit di Provinsi Riau perlu, mengingat bahwa Provinsi Riau merupakan salah satu provinsi sentra perkebunan kelapa sawit terbesar di Indonesia.

\section{UCAPAN TERIMA KASIH (ACKNOWLEDGEMENT)}

Ucapan terimakasih disampaikan kepada LPPM Universitas Lancang Kuning atas dukungan dana penelitian melalui program APBU.

\section{DAFTAR PUSTAKA}

Abnisa F, Arami-Niya A, Wan Daud WMA, Sahu JN, NoorM. 2013. Utilization of oil palm tree residues to produce bio-oil and bio-char via pyrolysis. Energy Convers. Manag. $\quad 76$ 1073-1082. doi:10.1016/j.enconman.2013.08.038

[BPS] Badan Pusat Statistik. 2019. Statistik Kelapa Sawit Indonesia. Jakarta (ID).

[BPPT] Badan Kajian dan Penerapan Teknologi. 2018. Out Look Energi Indonesia 2018. Jakarta (ID)

Bridgwater A V. 2012. [BPS] Badan Pusat Statistik. 2019. Statistik Kelapa Sawit Indonesia.

Fang C. 2011. Comparison of UASB and EGSB reactors performance, for treatment of raw and deoiled palm oil mill effluent (POME). Journal of Hazardous Materials. 189: 229-234. https:// doi.org/10.1016/j.jhazmat. 2011. 02.025

Hambali E. 2010. Peran teknologi proses dalam pengembangan agroindustri industri hilir kelapa sawit. Orasi ilmiah guru besar IPB (ID).

Haryanti A, Norsamsi, Putri SFS, Novy PP. 2014. Studi Pemanfaatan Limbah Padat Kelapa Sawit. Konversi. 3(2): 20-29.

Mattjik AA, Sumertajaya M. 2000. Perancangan Percobaan dengan Aplikasi SAS dan Minitab Jilid I 1 ed. Bogor. 